\title{
APLIKASI PEMESANAN MAKANAN BERBASIS WEB DI CATERING CINDELARAS PEKANBARU
}

\author{
Yuda Irawan ${ }^{1)}$, Herianto ${ }^{2)}$, Refni Wahyuni ${ }^{3)}$ \\ ${ }^{1,2}$ Sistem Informasi, STMIK Hang Tuah Pekanbaru, Jl. Mustafa Sari No 5, Pekanbaru \\ Email : yudairawan89@gmail.com ${ }^{1)}$,herianto.sy@gmail.com ${ }^{2)}$ \\ ${ }^{3}$ Teknik Informatika, STMIK Hang Tuah Pekanbaru, Jl. Mustafa Sari No 5, Pekanbaru \\ Email : refniabid@gmail.com ${ }^{3)}$
}

\begin{abstract}
This research discusses about Making Web-Based Food Ordering Applications at Catering Cindelaras Pekanbaru. The food ordering system at Cindelaras Catering still uses the usual method, namely to order food for customers or consumers must come directly to Cindelaras Catering and the waiter at Cindelaras Catering still records customer orders manually on paper. This application contains about processing food menu data and ordering from customers. This application is designed using the Unifield Modeling Language (UML) model. The method used is the waterfall method. The reason for using this method is because the waterfall method approaches systematically and sequentially in building a system. The process of the waterfall method that is on the execution of a system is done sequentially. The system produced will be of good quality, due to its implementation in stages so that it is not focused on certain stages. It is expected that with this application, it can facilitate the administration to process food ordering data at Cindelaras Catering.
\end{abstract}

Keywords : Applications, Data, Food Order Reports, UML, waterfall.

\begin{abstract}
Abstrak
Penelitian ini membahas tentang Pembuatan Aplikasi Pemesanan Makanan Berbasis Web di Catering Cindelaras Pekanbaru. Sistem pemesanan makanan yang ada pada Catering Cindelaras masih mengunakan cara hal yang biasa yaitu untuk memesan makanan pelanggan atau konsumen harus datang langsung ke Catering Cindelaras dan pelayan pada Catering Cindelaras masih mencatat pesanan pelanggan secara manual pada kertas. Aplikasi ini berisikan tentang mengolah data menu Makanan serta Pemesanan dari Pelanggan. Aplikasi ini didesain menggunakan model Unifield Modeling Language (UML). Metode yang digunakan yaitu metode waterfall. Alasan menggunakan metode ini adalah karena metode waterfall melakukan pendekatan secara sistematis dan berurutan dalam membangun suatu sistem. Proses metode waterfall yaitu pada pengerjaan dari suatu sistem dilakukan secara berurutan. Sistem yang dihasilkan akan berkualitas baik, dikarenakan pelaksanaannya secara bertahap sehingga tidak terfokus pada tahapan tertentu. Diharapkan dengan adanya aplikasi ini, bisa memudahkan administrasi untuk mengolah data pemesanan makanan di Catering Cindelaras.
\end{abstract}

Kata Kunci : Aplikasi, Data, Laporan Pemesanan Makanan, UML, waterfall. 


\section{PENDAHULUAN}

Teknologi dapat memberikan kemudahan bagi kehidupan masyarakat dalam berbagai hal, sehingga menjadi lebih efektif dan efesien. Perkembangan teknologi khususnya teknologi komputer berdampak pula pada perkembangan pada dunia usaha seperti dunia usaha kuliner. Catering Cindelaras Pekanbaru adalah merupakan suatu perusahaan yang bergerak dalam bidang usaha kuliner di Pekanbaru. Catering Cindelaras yang ada di Pekanbaru dengan lokasi yang mudah di cari dan dengan harga menu makanan yang relative murah. sistem pemesanan makanan yang ada pada Catering Cindelaras masih mengunakan cara hal yang biasa yaitu untuk memesan makanan pelanggan atau konsumen harus datang langsung ke Catering Cindelaras dan pelayan pada Catering Cindelaras masih mencatat pesanan pelanggan secara manual pada kertas. Hal tersebut menjadi lambatnya dalam memproses pesanan pelanggan, dan kesulitan dalam pembuatan laporan pesanan dan laporan keuangan pada Catering Cindelaras.

\section{LANDASAN TEORI}

\section{Sistem}

sistem adalah kombinasi elemen, unsur dan prosedur yang saling berhubungan dan bekerja sama dalam melakukan kegiatan pengolahan data yang dimulai dari pengolahan masukan (input), pemrosesan (processing) dan keluaran (output) untuk mencapai suatu tujuan.

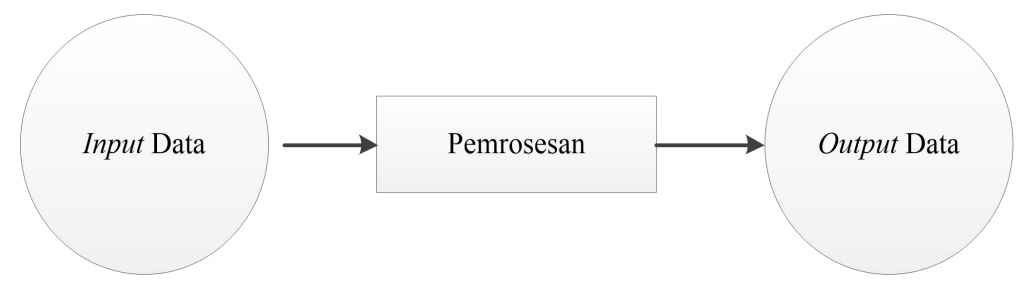

Gambar 1 Konsep Sistem

Dari gambar 1 di atas dapat dijelaskan bahwa suatu sistem terbentuk dari masukan yang ditunjukan kepada sistem tersebut dan mengolah masukan tersebut sampai menghasilkan suatu keluaran yang dibutuhkan.

\section{Web Aplication}

Web based application atau aplikasi berbasis web yaitu segala jenis aplikasi yang untuk dapat menjalankannya dibutuhkan akses ke internet [1]

Web based application adalah suatu aplikasi yang sebagian atau seluruh bagian dari software aplikasi tersebut didownload dari Web tiap kali aplikasi tersebut dijalankan [2]

\section{PHP (Hypertext Prepocessing)}

PHP merupakan kepanjangan dari Personal Home Page dan merupakan salah satu bahasa pemograman yang digunakan untuk pemograman aplikasi web 
Hal : $108-115$

Kelebihan dari PHP adalah mampu berkomunikasi dengan berbagai database, PHP juga sangat cocok membangun halaman web dinamis. Beberapa database yang dapat berkomunikasi dengan PHP diantaranya DBM, FilePro, Informix, Ingres, InterBase, Microsoft Access, MSQL, MySQL, Oracle, PostgreSQL dan Sybase.

\section{Database}

Basis data merupakan komponen utama dalam membangun sebuah sistem yang menyangkut pendokumentasian data ke dalam sebuah database. Bentuk basis data adalah sebuah aturan yang mengatasi masalah tersebut. Basis data memiliki peranan yang sangat penting dalam mengelola data yang ada di dalamnya.

Istilah basis data sering diartikan untuk sistem manajemen basis data (DBMS), akan tetapi basis data dan sistem manajemen basis data tidak sama. "Sistem Manajemen Basis Data atau Data Base Management System (DBMS) adalah suatu sistem perangkat lunak kompleks yang mengatur permintaan dan penyimpanan data ke dan dari disk”.(Simarmata, 2007:14)

\section{5. $M y S Q L$}

MySQL adalah salah satu perangkat lunak (software) sistem manajemen basis data relasional (relational database management system) yang bersifat "terbuka" (open source) artinya bebas untuk digunakan, diedarkan, maupun dikembangkan kembali oleh siapa saja tanpa harus khawatir dengan hak cipta. Keunggulan MySQL dapat dipasang pada server yang memiliki multi-CPU, didukung bahasa pemograman umum, dapat bekerja di multi-platform, verifikasi host sebagai keamanan sistem dan terintegrasi dengan PHP.

\section{6. $\quad$ UML (Unified Modeling Language)}

Unified Modelling Language (UML) merupakan sebuah "bahasa" yang telah menjadi standar dalam industri untuk visualisasi, merancang dan mendokumentasikan sistem piranti lunak. Unified Modelling Language menawarkan sebuah standar untuk merancang model sebuah sistem. Dengan menggunakan Unified Modelling Language dapat membuat model untuk semua jenis aplikasi piranti lunak, dimana aplikasi tersebut dapat berjalan pada piranti keras, sistem operasi dan jaringan apapun, serta ditulis dalam bahasa pemograman apa pun.

\section{METODE PENELITIAN}

Dalam melakukan penelitian, metode penelitian yang digunakan dalam penyusunan penelitian ini adalah waterfall. Secara garis besar metode waterfall mempunyai langkah-langkah sebagai berikut :

1. Analisa Kebutuhan

Langkah ini merupakan analisa terhadap kebutuhan sistem pemesanan makanan pada Catering Cindelaras. 
Hal : $108-115$

2. Desain Sistem

Tahapan dimana dilakukan penuangan pikiran dan perancangan sistem untuk sistem pemesanan makanan berbasis web pada Catering Cindelaras. Menggunakan perangkat pemodelan sistem dengan unified modeling language (UML) yaitu Use Case Diagram, Activity Diagram dan Class Diagram yang meliputi:

1. Design layout

2. Design use case

3. Penulisan Kode Program

Tahapan ini merupakan tahapan secara nyata yang diterapkan dalam sistem pemesanan makanan oleh pelanggan dengan mengunakan bahasa pemrograman PHP.

4. Pengujian Program

Tahapan akhir dimana sistem pemesanan makanan ini diuji kemampuan dan keefektifannya sehingga didapatkan kekurangan dan kelemahannya. Kemudian sistem pemesanan makanan ini dilakukan pengkajian ulang dan perbaikan terhadap aplikasi menjadi lebih baik dan sempurna. Dalam hal ini pengujian pada sistem ini menggunakan pengujian black box.

5. Penerapan Program dan Pemeliharaan

Pada tahap ini melakukan perawatan terhadap sistem pemesanan makanan pada Catering Cindelaras Pekanbaru.

\section{HASIL DAN PEMBAHASAN}

\section{Diagram Use Case}

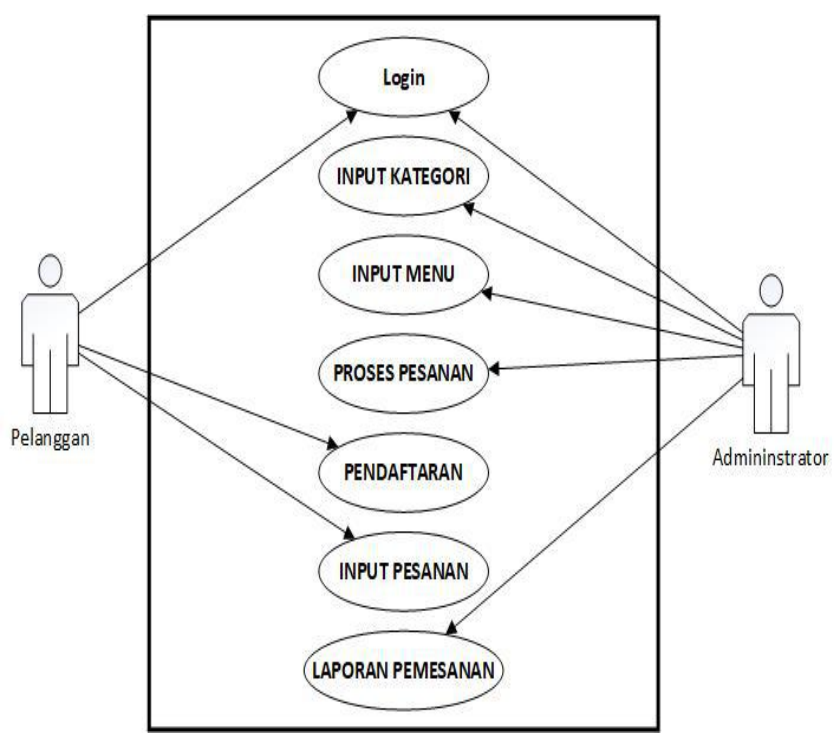

Gambar 2 Diagram Use case 
VOL. 2 No. 2, Desember 2019

$\mathrm{Hal}: 108-115$

\section{Administrator}

Diagram Activity Input Kategori

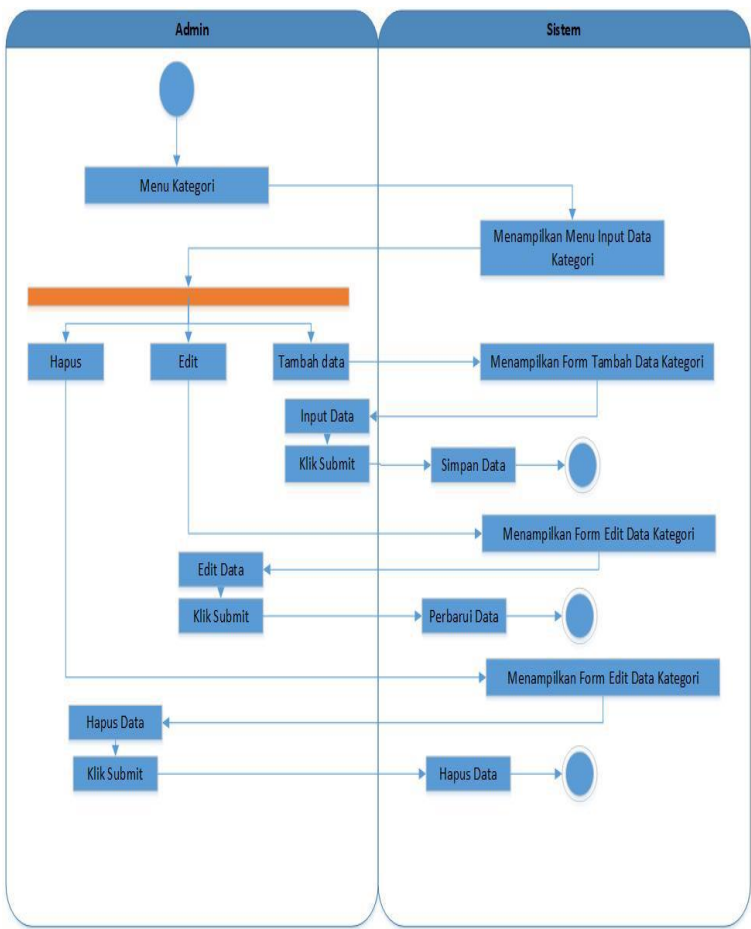

Gambar 3 Diagram Activity Input Kategori

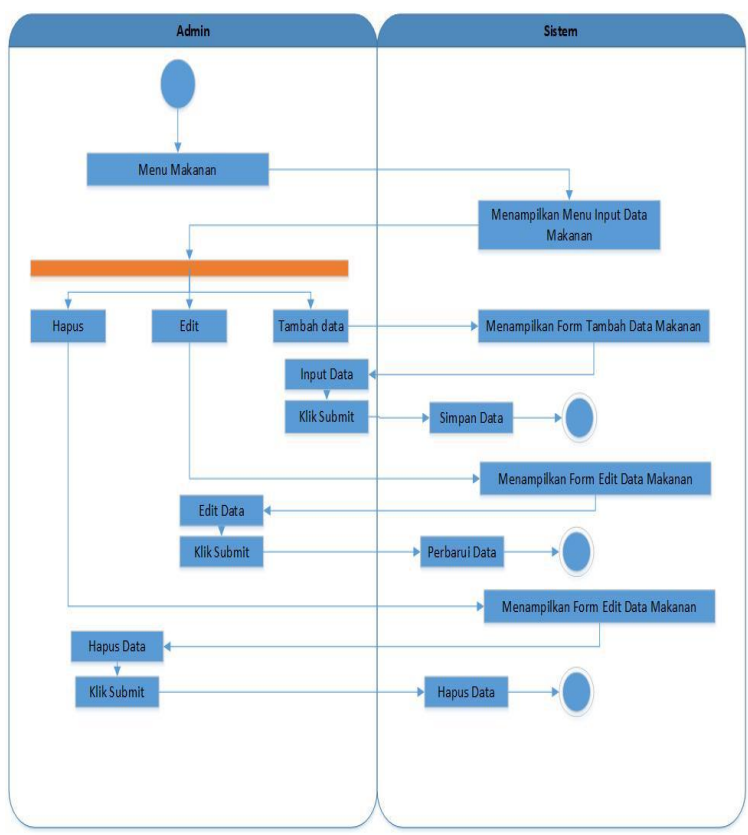

Gambar 4 Diagram Activity Input Makanan 
VOL. 2 No. 2, Desember 2019

Hal : $108-115$

2. Pelanggan

Diagram Activity Pemesanan

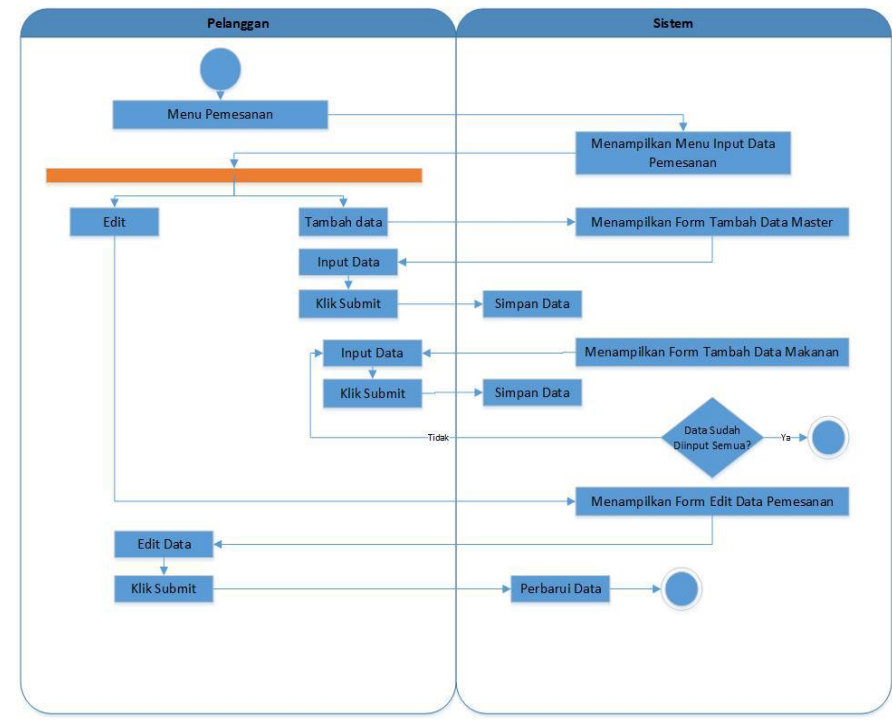

Gambar 5 Diagram Activity Pemesanan

\section{PEMBAHASAN}

\section{Tampilan Menu Halaman Utama}

Pada Menu ini merupakan halaman utama dari aplikasi pemesanan makanan pada catering cindelaras. Halaman ini berisikan data menu makanan catering cindelaras.
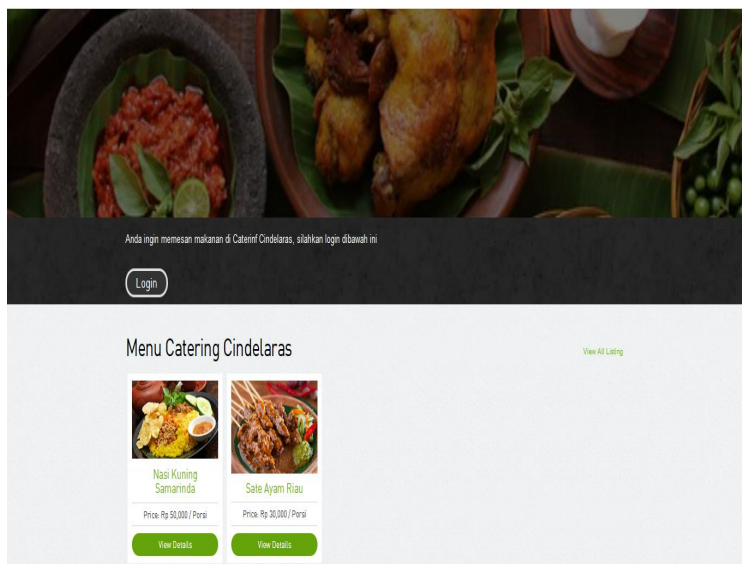

Gambar 6 Tampilan Menu Halaman Utama 
Hal : $108-115$

\section{Tampilan Menu Utama Detail Menu}

Pada Menu ini merupakan tampilan awal dari halaman utama mengenai detail menu makanan, gambar menu dan menu lainnya.

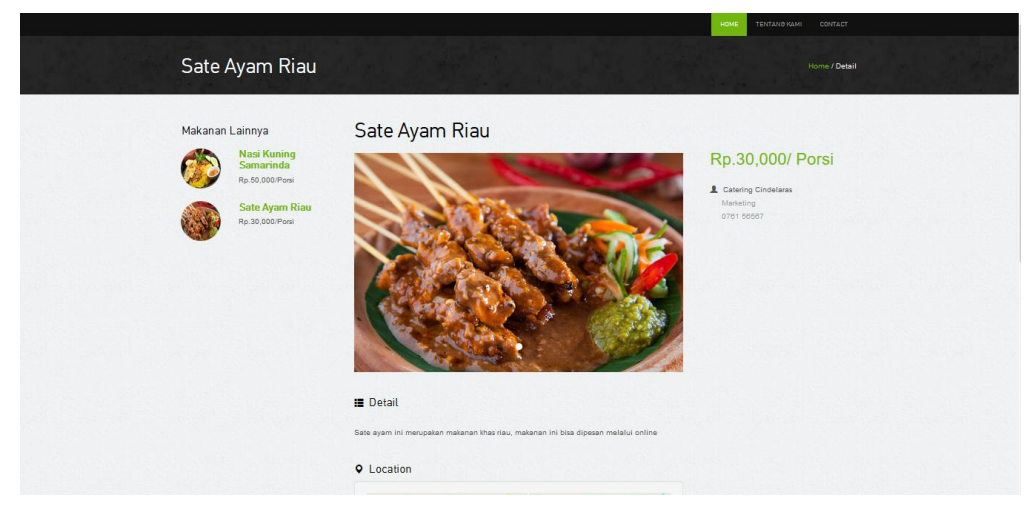

Gambar 7 Tampilan Menu Detail Makanan

\section{Tampilan Halaman History Pemesan}

Pada halaman ini, pemakai akan mengetahui riwayat pemesan makanan.

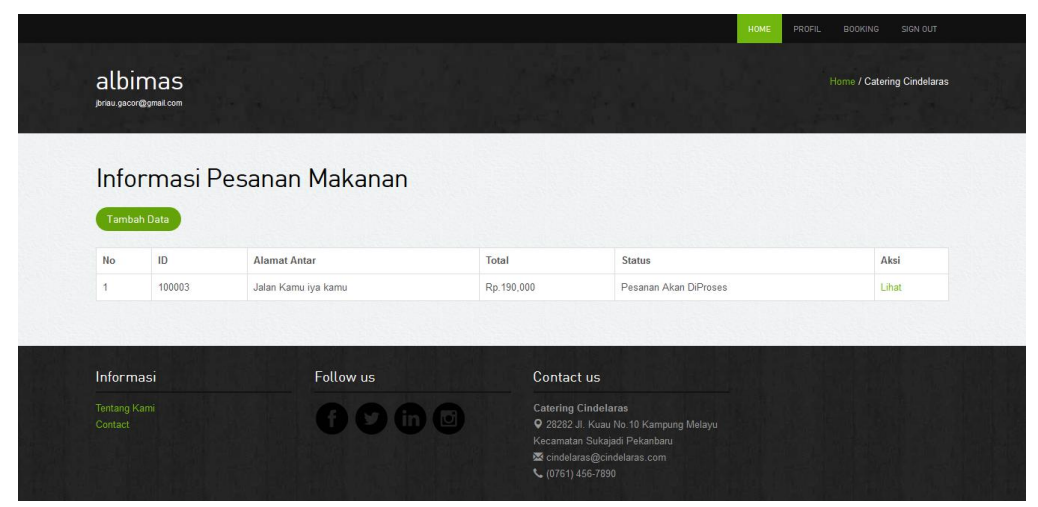

Gambar 8 Tampilan Halaman Daftar Histori Pemesanan 


\section{KESIMPULAN DAN SARAN}

1. Kesimpulan

Berdasarkan hasil penelitian dan pembahasan, maka kesimpulan yang dapat diambil dari penelitian ini adalah sebagai berikut :

1. Aplikasi ini dapat memberikan informasi yang cepat dan akurat dalam pemesanan makanan di catering cindelaras.

2. Aplikasi ini dapat membantu peningkatan omset dari catering cindelaras karena pemesanan bisa dilakukan secara online.

2. Saran

Saran-saran yang diberikan penelitian ini adalah:

1. Pengembangan aplikasi ini bisa di lengkapi lagi platform android sehingga dapat menyesuaikan dengan perkembangan teknologi sekarang.

2. Pengembangan aplikasi bisa dilakukan lagi untuk keamanan data pada database aplikasi ini, karena aplikasi ini merupakan aplikasi yang menyangkut masalah pemesanan makanan.

3. Menambahkan metode Customer Relationship Management untuk meningkatkan loyalitas pelanggan, seperti penelitian terdahulu oleh Yuda Irawan dengan judul Sistem Informasi Pemasaran Busana Syar'i Dengan Penerapan Customer Relationship Management (CRM) Berbasis Web[6].

\section{DAFTAR PUSTAKA}

[1] Abdul Kadir, 2008, Tuntunan Praktis Belajar Database Menggunakan Mysql, C.V. Andi Offset. Yogyakarta

[2] Al Fatta, 2007, Analisis Dan Perancangan Sistem Informasi, Andi, Yogyakarta

[3] Iswanto. 2007. Membangun Aplikasi Berbasis Php Dan Firebird. Yogyakarta: Andi

[4] Janner Simarmata, 2007. Perancangan Basis Data. Yogyakarta: Cv.Andi

[5] Y. Irawan, "Perencanaan Strategis Si / Ti Dengan Menggunakan Framework Ward And Peppard Di Sekolah Tinggi Ilmu Kesehatan ( Stikes ),” J. Ilmu Komput., Vol. 6, No. 1, Pp. 25-32, 2017.

[6] Irawan, Y. Sistem Informasi Pemasaran Busana Syar'i Dengan Penerapan Customer Relationship Management (Crm) Berbasis Web Syar'i Fashion Marketing Information System Using Web-Based Customer Relationship Management (Crm).

[7] Prahasta. 2014. Sistem Informasi Geografis Konsep-Konsep Dasar.(Perspektif Geodesi \& Geomatika). Informatika. Bandung

[8] Irawan, Y. (2018). Sistem Informasi Geografis Pemetaan Daerah Rawan Begal Berbasis Web Di Kota Pekanbaru. Riau Journal Of Computer Science, 5(1), 58-64.

[9] Hussein, S.O.K., Refni,W., Yuda, I., dan Harun,M. 2018. Sistem informasi deteksi kehadiran dan media penyampaian pengumuman dosen dengan menggunakan teknik pengenalan QR code. Jurnal Teknologi dan Sistem Informasi Univrab. 3 (2) : 89-99

[10] Irawan, Y. (2019). Aplikasi E-Commerce Untuk Pemasaran Kerajinan Tangan Usaha Kecil Menengah (UKM) di Riau Menggunakan Teknik Dropshipping. Jurnal Ilmiah Core IT: Community Research Information Technology, 7(1). 